\title{
EQUITABLE RELIEF IN CONTRACTS INVOLVING PERSONAL SERVICES.
}

Cases are, from time to time, coming before the courts, where equitable relief is asked for an actual or a threatened breach of a contract involving personal services. The most frequent type of case is where the plaintiff is the employer. But regardless of who the plaintiff may be, the terms of the contract in such a case may provide for, either, first, a fixed period of service, or, second, a fixed period of service, but with an option in favor of one of the parties to the agreement to end the same within such period, or, third, no fixed period of service, the employment being one that is frequently characterized as being at will. Where the plaintiff is the employer, the agreement may, or may not, be one that calls for the exclusive services of the employee, and in addition to this the employee may, or may not, be a person of unusual ability or reputation, or both. In a case where the plaintiff is the employee, the defendant may, or may not, have contracted to employ the plaintiff in his particular line of work to the exclusion of all others, and, further than this, the case may, or may not, present a situation where the defendant, if he lives up to his agreement and employs the plaintiff, will afford the latter a fine opportunity to advance himself in his profession, and to enhance his reputation. It is desired to discuss the various cases above enumerated, to determine to what extent equity has in the past given relief in the situations suggested, and should do so in the future. It is proposed to deal, first, with the cases where the plaintiff is the employer, and then with those where he is the employee.

\section{I.}

Where the employee is a person of merely mediocre ability, no equitable relief on principle seems to be needed by the employer, either in the case of an actual or a threatened breach of the agreement. ${ }^{1}$ Ordinary manual or professional labor is usually plentiful

${ }^{2}$ It may be that an injunction will be needed by an employer to prevent the disclosure of trade secrets, but that question is not germane to the one it is proposed to discuss. 
in the market, and so long as the employer can find other employees of the same grade and degree of skill, his remedy at law for the breach of the contract is adequate and complete. It has been suggested ${ }^{2}$ that no two men are alike, that each individual is a unique character, and consequently that equity should view the labor, the subject matter of the contract, as not being susceptible of duplication in the market. This contention, if correct, would of course warrant a court's giving equitable relief, if other conditions made it feasible. There is a certain plausibility in such an argument, but it is believed that there is a sufficient grade of sameness in the character of work produced by the ordinary person to justify the statement that the service (which is the thing contracted for) of such a person can be duplicated. It is conceded that there are differences in various individuals, but it is denied that these differences normally effect the uniformity of the quality of the work performed by each.

On the other hand, if an employee is a person of more than normal ability, if he is a specialist well trained in his field of work, or if he is a person of great reputation, he is unique; his ability and work cannot with any certainty be duplicated in the market. In such a case, the employer's remedy at law is inadequate, and a court of equity should, if it is possible, give him relief in the event of an actual or threatened breach of contract.

There are said to be certain practical difficulties in the way of compelling an employee to directly perform his agreement. It is not easy to obtain efficient work from an unwilling laborer; where an employee is discontented, disputes between him and his employer result, and, in the absence of harmony, it may well be that little benefit will result to either party, if it is attempted to enforce the contract. Accordingly, it is contended that if a court compelled a defendant to work under these conditions, that it would constantly be called upon to supervise the relations between

\footnotetext{
2 The late Dean Ashley, "Specific Performance by Injunction," 6 Columbia Law Review 82, p. 9r.

Apparently in Montague v. Flockton, Law. Rep. I6 Eq. I89, Malins, V. C., may have had the same idea in mind where he said, p. I99: "I must treat Mr. Flockton (the defendant) as if he were the greatest actor in the world, and, as if wherever he went the public would run after him."
} 
the parties, settle their disputes and direct and coerce the defendant. While it would seem possible for a court to do these things and to enforce its decree, nevertheless it would be highly inconvenient, consuming a great deal of the court's valuable time. Sa the rule has from early times been that no contract, obligating the defendant to give continuously of his labor and skill, will be specifically enforced by a direct affirmative decree. The court will not become a slave-driver in this sense of the word. ${ }^{3}$ It is believed, however, that the reasons for denying this kind of relief are not because the defendant's duty to serve is unrecognized, nor because the plaintiff's cause of complaint is without merit, but only for the reason that the court's machinery is not readily adaptable to giving the requisite amount of supervision to the enforcement of its decree. ${ }^{4}$ The court cannot, in other words, assume the duties of managing the plaintiff's force of employees. This rule is established, so far as is known, without any dissent. It has always seemed to the writer that these practical difficulties are not insurmountable. If the decree were actually made, while there might be some disputes, their recurrence would depend largely upon the manner in which the court exercised its discretion in adjusting the first one to arise. It used to be the rule in the analogous line of cases of building contracts, and contracts involving the operation of railroads, that specific performance of those agreements would not be decreed for the very same reason; yet the later, and, it is urged, the better considered cases have given affirmative relief in these classes of cases, and the decrees

${ }^{2}$ Kemble v. Kean, 6 Simons 333; Whitwood Chemical Company v. Hardman, I891, 2 Chanc. 416; Rogers Manufacturing Co. v. Rogers (Conn.), 20 At1. 467; Hamblin v. Dinneford (N. Y.), 2 Edw. Chanc. 529.

- There are occasional instances where the courts have given as an additional reason for denying specific performance, that it would be unjust and against public policy to compel one man to work for another against his will. It is said that such a decree would be mischievous in its results: See remarks of Fry; L. J., in De Francisco v. Barnum, Law Rep. 45 Chanc. Div. 430, p. 438; Arthur v. Oakes, 63 Fed. 310, p. 3I7; Boyer v. Western Union, 124 Fed. 246, p. 249.

It has also been held that as the only way of enforcing the decree is to commit the defendant for contempt, the very object desired will be unob-tainable if the court interferes, for the defendant cannot perform the contract in prison, Hamblin v. Dinneford, supra, note 3 . 
have been carried out. ${ }^{5}$ A defendant can live with and work for another, if he has to, and the court can, if it will, make it clear that this has to be done. ${ }^{6}$

The question remains, conceding that direct specific performance cannot be given, is the employer to be without any equitable remedy? Suppose that both parties are equally bound for a definite period, that the employee agrees to give his exclusive services to the employer, and that he then either breaks, or threatens to break, his contract. In the United States the courts have very generally, if the employee is a person of unusual or unique ability, enjoined him for the period of the contract from working for any person other than his employer; probably this relief would be given wherever the defendant's real obligation is to work solely for the plaintiff, regardless of the form of the contract; by this it is meant that the obligation not to work for another can be implied, and does not have to be expressed in a negative covenant. ${ }^{7}$ The injunction can be viewed in either of two ways. It can be said that the court is indirectly endeavoring to specifically enforce the agreement to work, or that the court is only taking so much of the agreement as is specifically enforceable (i. e., the agreement not to work elsewhere), and enforcing it. Undoubtedly the result of the injunction frequently is to

Jones v. Parker, I63 Mass. 564; Prospect Park, etc., R. R., v. Coney Island, etc., R. R., I44 N. Y. I52; Central Trust Company v. Wabash, etc., $R . R_{i} 29$ Fed. 546, p. 558; Hood v. North Eastern Ry. Co., Law Rep. 8 Eq. 665 ; Lane v. Newdigate, ro Vesey 192.

In some of the above cases the decree took the form of enjoining the defendant from doing acts inconsistent with his contract, but this, it is submitted, is nevertheless giving direct specific performance.

In the railroad cases the courts were sometimes influenced by the fact that the public had an interest in having the railroad operated as agreed upon. See Standard Fashion Co. v. Siegel Cooper Co., I57 N. Y. 60, p. 66.

- It has never been deemed improper or impossible to coerce a deserting seaman into returning to his ship and his duties.

'In the following cases the defendant was enjoined from entering the employ of a person other than the plaintiff: Duff v. Russell, I4 N. Y. Supp. I34; affd. I33 N. Y. 678 (negative agreerrent implied) ; Hoyt Y. Fuller, I9 N. Y. Supp. 962 (negative agreement implied); Philadelphia Ball Club v. Lajoie (Penn.), 5 I Atl. 973 (express negative agreement); Buttrick Publishing Co. v. Rose (Wis.), 124 N. W. 647 (express negative agreement); Cincinnati Exhibition Co. v. Marsans, 2I6 Fed. 269 (express negative agreement); Comstock v. Lopokowa, I90 Fed. 599 (express negative agreement); Keith v. Kellerman, 169 Fed. 196 (express negative agreement).

In the following cases an injunction was denied in spite of defendant's 
compel the defendant to work his agreement out; usually a man cannot afford to stay idle, but this is not the essential result; the defendant does not have to perform the services and the court will not concern itself with the question of whether he does or does not do this. It cannot, therefore, correctly be said that the injunction is the giving of specific performance of an agreement to render personal services. The other view as to the injunction is sound. Ari agreement to work exclusively for A is the equivalent of an agreement not to work for anyone else. Why then should the court not compel the employee to live up to the stipulations, particularly when the fact is recalled that the latter is an unusual person in his ability or reputation, and that money compensation will not give the employer complete relief? The court is then doing all that it can for the plaintiff, and in granting its decree has not involved itself in any of the supposed difficulties, which it is claimed would result if the affirmative contract were enforced. For these reasons the issuance of the injunction seems alfogether just and practicable.

It sometimes happens that the employee does not agree to give the employer the whole of his time, and no such agreement can reasonably be implied, but the employee is a person of unique ability or reputation. Under such conditions, it is submitted, it is impossible for a court to give the employer any equitable relief that would be of any substantial benefit. It is conceived that the employer would be entitled to an injunction restraining the defendant from working for persons other than himself during

express or implied agreement to serve no one except the plaintiff, because he did not appear to be a person of unusual skill or reputation: Rogers Manuf. Co. v. Rogers, supra, note 3 (express negative agreement) ; Burney v. Ryle (Ga), 17 S. E. 986 (agreement to give entire time); Gossard Co. v. Crosby (Iowa), Iog N. W. 483 (agreement to give entire time); Rosenstein v. Zent (Md.), 85 Atl. 675 (express negative agreement); Cort v. Lassard (Ore.), 22 Pac. r054 (agreement to give entire time); Lasky Feature Play Co. v. Surratt I54 N. Y. Supp. 974 (it is not apparent from the report whether the defendant bound herself negatively or not); Johnston Co. v. Hunt, 22 N. Y. Supp. $3^{14}$ (express negative agreement).

In Gossard Co. v. Crosby, supra, it was said that no injunction should ever issue in the absence of an express negative agreement. But in Cort v. Lassard, supra, it was held that an injunction could be based upon an implied negative agreement if the defendant was a person of unusual ability. Each of these statements is to be regarded as dictum. 
the period that he was obligated to work for the latter (for that is the agreement), but such a decree leaves the defendant free in between such times to work for others; he could at such times give aid and comfort to the employer's rivals, and would not be deprived of his means of livelihood; so such a decree is of no real value. It might be suggested that the court could issue an injunction forbidding the defendant working for anyone else, at any time during the life of the contract. The objection to this is that the defendant never agreed to such a course of conduct; the court would be compelling the defendant to do more than he had ever agreed to, and would here really be endeavoring indirectly to compel specific performance of the affirmative agreement to work. That would be manifestly unjust, and would be adopting, to say the least, an extreme method to secure performance. In this class of cases the employer must look to legal remedies for relief.

As already intimated, contracts sometimes provide for the continuance of the relation of employer and employee for a stated time, with a provision, however, that the agreement may be terminated at the option of one of the parties within such period. It is possible for the option to be in favor of either party, but usually it is in favor of the employer, and gives him the right to end the contract for any cause sufficient to himself, upon giving a certain amount of notice in advance and paying the employee's salary until the time for ending the contract pursuant to the notice arrives. In some jurisdictions, no matter what the nature of the services to be rendered may be, such a contract is not specifically enforceable in any sense of that term, nor will any relief in equity be given thereunder. ${ }^{8}$ This is so even where the plaintiff has no desire to terminate the contract, and comes asking relief in the utmost good faith. Under this line of decision the contract is said to lack mutuality of obligation, and to be essentially unfair, because one party is bound while the other one is free. Furthermore, it is claimed, if the

${ }^{8}$ Brooklyn Base Ball Club v. McGuire, II6 Fed. 782; Lawrence v. Dixie, I04 N. Y. Supp. 516; Dockstader v. Reed, I06 N. Y. Supp. 795; Rust v. Conrad, 47 Mich. 449 ; Marble Co. v. Ripley, to Wall. 339. 
plaintiff does gain an injunction, the court might well be doing a vain thing, inasmuch as the plaintiff has, by the terms of the agreement, a perfect right at any time to dissolve the injunction by electing to end the agreement. If the plaintiff did this, the cases say, he would be nullifying the very injunction that was previously granted at his request. ${ }^{9}$

Such a contract may sometimes be a hard one. On the other hand, it is more than likely that when an employee makes a contract, which entails the risk of its being cut short at the employer's option, he offsets the same by demanding and securing a higher rate of wages than he would otherwise have gotten. Moreover, such a clause in the contract is frequently essential for the protection of the employer to keep the employee "keyed up" to the proper pitch in the performance of his duties. ${ }^{10}$ It is believed that it is not sound or true to say that all contracts, containing a condition of this nature are unjust; each case should be judged by itself, and relief given or withheld, depending upon the particular situation presented. Of course, if an injunction were to issue, it goes without saying, that its life should in justice to the defendant be conditioned upon the plaintiff's not terminating the contract by exercising his option. As to the contention that the court might be doing a futile thing, because the plaintiff is still free to terminate the contract-that objection does not appear to be valid; it should not be assumed that the employer is bringing his action merely to persecute the defendant, but rather with the end in view of preventing the defendant from hiring himseli to another in violation of his contract. Even if the plaintiff should elect to terminate the agreement after he had gained his injunction, it is difficult to imagine that the court's dignity will suffer to an appreciable degree as a result. There is at least one jurisdiction holding that so-called lack of mutuality of obligation

\footnotetext{
- Rust v. Conrad, supra, note 8.

${ }^{10}$ This clause, when the defendant has broken his agreement, has obviously failed to produce the desired result, but still it may well be that the plaintiff has justifiable reasons for retaining the defendant for the period
} 
does not prevent equitable interference if an actual or threatened breach occurs. ${ }^{11}$

Where the contract provides for employment at will, either party being free to end the same at his pleasure, there is clearly no basis for equitable interference at the instance of either party. In such a case there is no obligation of any kind that can be specifically executed.

The English decisions in all these types of cases apparently require an express negative covenant on the part of the employee not to work for a person other than the plaintiff, before an injunction will be granted. Although the later decisions do not expressly hold this, and intimate that a negative covenant might in some circumstances be implied, still the result of the cases justifies the belief that it is hardly possible to conceive of a case where a plaintiff employer may get an injunction unless he has bound his employee negatively as well as positively. The leading case is still Lumley v. Wagner. ${ }^{12}$ There Wagner, an opera singer, agreed to sing at the plaintiff's theater a certain number of nights during a season, and further bound herself not to sing elsewhere during that time. The plaintiff obtained a decree, forbidding defendant singing for one Gye, a business rival, for the life of the contract. Lord St. Leonards, who decided the case, based his injunction on the express negative covenant. It was admitted by the court that it could not, and would not, compel the defendant to sing, but even so the defendant had bound herself not to sing elsewhere, this was a good contract in and of itself, susceptible of specific execution, and so an injunction was issued compelling the defendant to live up to this portion of her agreement. It will be observed that the ratio decidendi of the decision is that while the court cannot compel the performance of services, it can compel a defendant not to do an act that he or she has engaged not to do. So if there be coupled to an agreement to

of the contract, as, for instance, preventing his combining with a business rival.

${ }^{11}$ Philadelphia Ball Club v. Lajoie (Penn.), 5I Atl. 973. See also Cincinnati, etc., Co. v. Marsans, 216 Fed. 269; Hoyt v. Fuller, 19 N. Y. Supp. 962 .

${ }^{12}$ I De. G. M. \& G., p. 604 
serve an express obligation not to serve anyone else, the court will enforce the latter and leave the former untouched. This, as has been already pointed out, is not doing indirectly what the court cannot do directly. The decision on this point is sound, conflicting with no established principle. But the court did not stop with the actual decision, and in the course of its opinion let fall statements that there would have been an implied obligation on the part of the defendant not to sing elsewhere, even if she had not expressly agreed to this effect, but that under those conditions the injunction could not have been issued. ${ }^{13}$ The court evidently felt that there was a distinction between a mere positive agreement to sing exclusively for the plaintiff, and such an agreement plus the negative one. The former standing alone, would only afford grounds for decreeing that the defendant sing (which could not be done), while the latter would afford grounds for forbidding the defendant singing clsewhere.

This dictum was naturally received with great respect and became the basis of the rules formulated in later decisions. In Whitwood Chemical Company v. Hardman, ${ }^{14}$ the defendant agreed to give the plaintiff the whole of his time for a specified period, but he did not agree expressly not to serve anyone else. The court refused to forbid the defendant breaching his contract by associating himself with plaintiff's business rivals, because the defendant had not expressly promised not to serve anyone else, and the court did not see its way clear to imply such an obligation. Lord Lindley said ${ }^{15}$ that there was nothing to indicate that the parties had contracted in the sense that he was bound not to do, what he was about to-there was not some specific thing mentioned, which the defendant had agreed not to do "upon which you can put your finger." This being the case, the court held that if it were to enjoin the defendant, what it would be doing in effect would be granting indirect specific performance of the affirmative agreement to work. It will be seen from this

\footnotetext{
${ }^{12}$ I De. G. M. \& G., pp. 6I8, 6I9, 622.

"Law Rep. I8gI-2 Chanc. 416.

${ }^{15}$ Law. Rep. I89I-2 Chanc., pp. 426, 427.
} 
decision to what extent the dictum of Lord St. Leonards in Lumley v. Wagner has been carried, resulting, as was said above, in its being well-nigh impossible to enjoin an employee, no matter how unique his ability may be, or how much damage he' may cause his employer unless he has bound himself in negative terms. ${ }^{10}$

Inasmuch as the question is not one of mere academic importance, for there is as yet no large amount of case law on this point in this country, it is believed proper to suggest that the English rule is not logical and should not be followed. As has already been intimated, it is only correct to say that an agreement to give the plaintiff the whole of one's time or one's exclusive services creates an obligation to serve the employer alone and no one else. If that is the case, the negative covenant is just as strongly present, even though it is not written into the contract, and in fact the writing of it is mere verboseness and surplusage. ${ }^{17}$

The English decisions do not require as the basis for the issuing of an injunction the presence of any element apparently except the negative covenant. The question of whether or no the defendant is a person of unique ability or reputation, is nowhere discussed, much less made a decisive feature in any given case. It is undoubtedly true that in most instances, where the defendant has been enjoined, he was a person standing high

* See accord, Mutual, etc., Assn. v. New York, etc., Co., 75 L. T. 528. But see Metropolitan, etc., Co. .v. Ginder, I901-2 Chanc. 799, where a negative agreement was implied in a somewhat analogous though distinguishable case and an injunction issued.

${ }^{17}$ See Donnell v. Bennett, Law. Rep. 22 Chanc. Div. 835, where Fry, L. J., reluctantly followed the rule laid down in Lumley v. Wagner, as to negative covenants, but said, page 837 , that it seemed to him that, "the court ought to look at what is the nature of the contract between the parties; that if the contract as a whole is the subject of equitable jurisdiction, then an injunction may be granted in support of the contract, whether it contain or does not contain a negative stipulation; but that if on the other hand the breach of the contract is properly satisfied by damages, then that the court ought not to interfere whether there be or be not the negative stipulation."

There is very little modern authority on this question in this country, but no American case is known to the writer, where the injunction was denied solely because there was no express negative agreement. There has always been some other equally controlling reasons (than the absence of the agreement) for denying relief. See supra, note 7 . 
in his profession, but this fact does not seem to have influenced the court in giving relief, ${ }^{18}$ and occasionally relief has been given where that did not appear to be the situation. ${ }^{19}$

The question still remains as to the terms of the injunction, when it is issued in any case; under what condition, and for how long should the defendant be forbidden to work for anyone except the plaintiff? Obviously, if the plaintiff is in default, he is entitled to no relief, and the cases so hold.20 But supposing the plaintiff is not in default, should the injunction issue blindly and arbitrarily, regardless of what the plaintiff's conduct may turn out to be during the life of the same? There are some cases that have done this very thing with apparently entire satisfaction with the result brought about. ${ }^{21}$ Such a decree is unjust and uncalled for. Even though the defendant has broken his agreement, he should not be compelled to return to its performance even partially, unless the plaintiff is ready and willing to perform his side, if the defendant will return to his employ. The proper decree would be to make the life of the injunction conditional upon the plaintiff's standing ready and willing at all times to employ the defendant as agreed upon, and actually paying the latter his salary if he resumes his duties. A decree of this nature has also sometimes been given, ${ }^{22}$ and is just, giving the plaintiff all possible relief and at the same time safeguarding the defendant against any undue oppression. There is another line of decision that has gone even further than this in protecting

${ }^{13}$ See remarks of Kekewich, J., in Whitwood Chemical Co. v. Hardman, I $892-2$ Chanc. 416, p. 420 , to the effect that relief is given because the defendant's services cannot easily be replaced. This decision, however, was reversed by the Court of Appeal, supra, note i4.

10 Grimston v. Cunningham, I894-I Q. B. 125 (defendant an understudy); Robinson v. Heuer, I898-2 Chanc. 45I (defendant a clerk). See also, Donnell v. Bennett, Law Rep. 22 Chanc. Div. 835, where defendant had agreed not to sell ordinary personal property to anyone except the plaintiff, and was accordingly enjoined.

- Fechter v. Montgomery, 33 Beavan 22; Pratt v. Montigriffo, ro N. Y. Supp. 903 ; Rice v. D'Arville, 162 Mass. 559.

In Lumley v. Wagner, supra, note 12 , the injunction so far as appears, imposed no conditions on the plaintiff's conduct; Montague v. Flockton, Law Rep. I6 Eq. I89.

2 McCaul v. Braham, I6 Fed. 37, p. 42; Taylor Iron \& Steel Co. v. Nichols (N. J.), 69 Atl. 186, p. I89; Standard Fashion Co. v. Siegel Cooper Co., $60 \mathrm{~N}$. Y. Sup. 739, p. 744 (presenting an analogous question, but not in an employer's action). 
the defendant's rights, by holding that the injunction will be granted, only if the plaintiff pays the defendant his salary no matter whether the latter renders the services called for or not. ${ }^{23}$ This is going too far, and is working an unjustified and unnecessary hardship on the plaintiff. Why should the defendant be placed in a better position than he would have been in had he not breached the contract, and this, too, without living up to the terms of the same? So long as the decree requires of the defendant nothing more than he has agreed to, and assures to him if he does do this all the benefits that he is entitled to under the agreement, he should have no cause for complaint; indeed, he has no right to expect anything more.

It has been suggested as a ground of objection to equitable interference in behalf of the employer in a contract of this kind, that the situation resulting, if the injunction is issued, would lack mutuality of remedy, $i$. e., that the court ought not to interfere because it cannot compel the plaintiff to perform his side of the agreement. This being the case, it is said that it is unjust to compel the defendant to remain idle or work for the plaintiff. It will have to be admitted that as a general rule equity can no more compel an employer to hire than it can compel an employee to work. The same reasons that deter the court from interfering in the latter case deter it from interfering in the former, ${ }^{24}$ but it is denied that it follows from this that the granting of the injunction is unjust, or that there is a legally objectionable lack of mutuality of remedy presented if it is granted. As to the more general objection-if the injunction is framed so as to make its continuance dependent upon the plaintiff's readiness to employ and actually paying the defendant at the agreed rate if he does work, no injustice can be done the latter. If the plaintiff does not fulfill the required conditions the injunction can forthwith be vacated. ${ }^{25}$ In regard to the more specific objection that the situation presents lack of mutuality of remedy, if that term is correctly understood there is no lack of it here. Assume that $\mathrm{A}$

2 Cincinnati Exhibition Co. v. Marsans, 216 Fed. 269.

${ }^{2}$ See, supra, note 3. p. 672 .

${ }^{25}$ General Electric Co. v. Westinghouse Electric Co., 15I Fed. 664, 
agrees to sell $B$ a race horse and to pass title to the same today, and $B$ agrees in return to pay $A$ by riding the horse in various races and dividing its winnings with $A$. This being the contract, suppose $B$ seeks specific performance, the court would deny relief, because its decree would compel $A$ to completely perform by transferring title to the horse before B's obligation arose, and the court would not then be able to assure to $A$ the performance by $B$ of his obligation, owing to its nature. This is a case where there is a true lack of mutuality of remedy. Wherever a contract by its terms requires complete performance by the defendant, before the plaintiff's obligation arises, and the court cannot compel the plaintiff to perform the same, it will not specifically execute the contract; to do so would be clearly unjust; the defendant would be compelled to substantially and irretrievably change his position without any real assurance that the plaintiff would give him in return specific performance of his obligation. ${ }^{20}$

The ordinary contract for personal services does not present any such difficulties, nor does an injunction, if issued, place the defendant in a similar position of hardship; by the terms of the agreement, the defendant is not called upon to completely perform his side of the agreement before the time for performance by the plaintiff accrues; the obligations of each party run along side by side; as the defendant serves the plaintiffs pays, and whenever the plaintiff ceases to pay the defendant, under a proper kind of a decree, the latter may cease to work; the injunction, when that state of affairs comes to pass, should no longer be binding upon the defendant. ${ }^{27}$ Accordingly, it is submitted there is no lack of mutuality of remedy; the injunction, if obeyed, does not convert the contract into a unilateral one completely executed on the defendant's side, but executory on the plaintiff's

* Wakeham v. Barker, 82 Cal. 46; Buck v. Smith, 29 Mich. I66, p. I72; Flight v. Bolland, 4 Russell 298.

"General Electric Co. v. Westinghouse Electric Co., supra, note 25; Great Lakes, etc., Co. v. Scranton Coal Co., 239 Fed. 603, p. 609, where the true rule is expressed as follows: "If specific performance be otherwise proper, equity is no longer deterred from granting its aid because of a so-called lack' of mutuality of remedy. It suffices that defendant's compulsory performance is conditioned upon plaintiff's continued readiness to carry out his obligation." See also, Stocker v. Wedderburn, 3 K. \& J. 393, p. 404 . 
side. Moreover, if the plaintiff happens to be in arrears as to payments of salary which the defendant may have earned, it is entirely possible for the court to decree that the deficiency be made good, so that complete justice can be done on all sides.

Occasionally it has been said that enjoining a defendant employee from working for anyone except the plaintiff is unjust and against public policy, ${ }^{28}$ and is in effect placing him in a state of involuntary servitude, contrary to the Thirteenth Amendment of the Federal Constitution, ${ }^{29}$ because the almost invariable result of the injunction is to compel.the defendant to work for the plaintiff. If the contract is fair (which is the only kind of $a$ contract that equity ought ever to enforce), it has always seemed to the writer, that it is only just for the court to endeavor to get for the plaintiff the fruits of his bargain. It is surprising how little attention the possible constitutional question, as to involuntary servitude, has received from the courts. So far as is known, there is no decision squarely passing on this point. ${ }^{30}$ It is believed, however, that the Thirteenth Amendment is not aimed at this kind of a "servitude." It was not intended to introduce any "novel doctrine." It was not intended to disturb long-established rights (other than slavery and peonage, etc.), which had always, up to the time of its adoption, been recognized by society and the courts, as being legitimate and proper. ${ }^{31}$ The employer's right under proper conditions to enjoin his employee from breaking his contract is of such a nature. The granting of the injunction had rarely been characterized as being an invdsion of the employee's personal liberty. ${ }^{32}$

\section{II.}

Turning to the cases where the employee is the plaintiff and he seeks relief in equity against the employer, there will be found

${ }^{3}$ Supra, note 4 .

${ }^{20}$ Arthur v. Oakes, 63 Fed. 310, p. 317.

${ }^{\infty}$ It is stated in Willoughby on The Constitution, Section 459 , that a decree would be in contravention to the Thirteenth Amendment, and that an employer's only remedy is an action at law.

mobertson v. Baldwin, 165 U. S. 275, p. 282.

${ }^{32}$ This statement is not to be taken too broadly; the notion has prevailed in some quarters that equitable interference, bringing pressure to 
very little authority to aid in formulating any rules. It has been stated already, and it is the law, that the employee cannot get direct specific performance from the employer. ${ }^{33}$ The relation is essentially personal, and the enforcement of a decree for specific performance would require the court's constant supervision. But even so, is the employee entitled to no relief? Is his remedy at law adequate and complete? Normally the employee is working for his wage; wherever this is the case the recovery of damages affords ample relief. Suppose, however (and the assumption is not unwarranted), that the employee, besides looking for lucre, is seeking a chance to make a name and reputation for himself, and the place which the defendant has agreed to give him will afford an unusual opportunity for the attainment of this end. Here is a situation where the subject matter of the contract (i.e., the chance to learn and to gain a reputation) is unique; damages for breach of the contract will not give the plaintiff a satisfactory remedy. In spite of this fact, it is not seen how a court of equity can aid the employee. It could not enjoin the employer usually from employing anybody else, for he neither expressly nor impliedly agreed to this effect. The employer is usually free under the terms of the contract to hire as many persons as he desires, and this being the case, the court could not with propriety go so far as to compel the defendant to virtually cease all business activity, unless he performs his agreement to employ the plaintiff. This is a case, to use Lord Lindley's expression, where there is no "specific thing (i.e., agreement) upon which you can put your finger." 34 Here, in spite of the text-writers, equity suffers a wrong to go unremedied. It might be, however, that the defendant had agreed either expressly or by implication to employ the plaintiff for a definite length of time in his particular line of work, to the exclusion of all other persons, and (to

bear upon the employee, is repugnant to the American conception of personal liberty.

2Davis v. Forman, 1894-3 Chanc. 654; Kinnicott v. Leavitt, 37 IIl. App. 435; Healey v. Allen, 38 La. Ann. 867; Greer v. Austin (Okla.), I36 Pac. 590 ; Boyer v. Western Union, I24 Fed. 246, p. 249 (dictum).

* Supra, note 5 . 
make it more certain) to employ no one else in a similar position for the term of the contract. Under these circumstances, it is believed that if the opportunity that would be afforded the plaintiff would be unique, in the sense that this word is explained above, that the court might well enjoin the defendant from hiring another, conditionally upon the plaintiff's standing ready and willing to fulfill his obligation if the defendant will permit him. For example, suppose the defendant contracts to employ the plaintiff, a young actor, in the leading part in a specified play, at an agreed theater for a stipulated season, and then threatens to or actually does repudiate his contract. The plaintiff has his reputation to make; the defendant has agreed to give him a great opportunity; can it not be said that equity could, in the light of the reasoning adopted in actual decisions, with perfect propriety, forbid the defendant using the theater during the life of the contract for any purpose other than staging the play as agreed upon? Surely the defendant had covenanted not to do these things and the injunction is logically and justly asked for ${ }^{35}$ it is believed that the injunction should issue whether the defendant has bound himself negatively or not.

. It seems needless to add that the employee could not get relief under any conditions if his employment were one at will; nor could he, in those jurisdictions, where a contract must be mutual in its obligation, if that element were not present in any given case. ${ }^{36}$

\section{J. Lewis Parks.}

\section{Indiana University School of Law.}

* In Lacey v. Heuck, 9 Ohio Dec. Reprint 347, Boke's Cases on Equity, p. I9I (the official report of this decision not being available has not been examined), defendant agreed to give plaintiff the use of his theatre with necessary service for the production of a play. An injunction issued, restraining the defendant from letting the theatre be used by persons other than plaintiff during the period of the contract, or from putting the theatre to any other use than the production of plaintiff's play. The court properly refused to compel the defendant to operate the theatre. See also, Standard Fashion Co. v. Siegel Cooper Co., I57 N. Y. 60. But see apparently, contra. Jones v. Williams (Mo.), 40 S. W. 353; Mair v. Tea Co., Law. Rep. I Eq. 4 I0.

* The collection of cases on equity of the late Dean Ames and the excellent editorial note in $6 \mathrm{~L}$. $R$. A. (N. S.) III5, have been of the greatest assistance to the writer in finding the authorities. 